\title{
THE POLITICS OF POPULATION PLANNING IN MALAYSIA AND THE PHILIPPINES
}

\author{
GAYL D. NESS
}

University of Michigan

with

HIROFUMI ANDO

E.C.A.F.E., Bangkok

Rapid population growth has been emerging as an ecological problem over the past two or three centuries. It has emerged as a political problem only in the past decade. The gradual control over mortality has brought a long-term increase both in population density and in the rate of population increase in the world as a whole. The resulting ecological pressures brought a variety of adjustments in the form of population movements and changes in technology and social organization, also extending over a relatively long time period. More recently, population growth has come to be identified as a political problem, or a problem in national policy, in conjunction with a commitment to economic growth. Such an identification brings an adjustment in terms of specific national policy aimed at the control of population growth.

AUTHORS' NOTE: The materials for this paper were gathered as part of a larger study of the political and administrative aspects of family planning programs in Malaysia and the Philippines. Research for this publication was supported in part by funds provided by the Agency for International Development's 211 (D) Grant (CSD-2171) to the Center 
Both this identification and its adjustment have been recent and relatively rapid. Of the 102 countries the Population Council (1968) classified as developing countries on the basis of high fertility levels, 42 have accepted population control as an aim of national policy. Only 2 of these countries developed such policies prior to 1960 (India in 1952, Hong Kong in 1956), and 33 developed policies between 1965 and 1970.

A political adjustment, as opposed to an ecological adjustment, implies a more limited range of institutional changes. It implies a collective identification of a problem and a collective decision to mobilize resources for and allocate them to the solution of the problem. Broadly speaking, the issues involved in a political adjustment include the relation between the character of the polity, the process of collective decision-making, and the process of implementation. We can profitably begin an analysis of these issues by focusing on a limited number of countries in the process of making the political adjustment to rapid population growth. From this, we might hope to identify the aspects of the polity that affect both the process of decision-making, and the character of the policy that emerges from the collective decision.

For this limited clinical comparison, we use Malaysia and the Philippines. In 1960, both Malaysia and the Philippines

for Population Planning, the University of Michigan. The viewpoints expressed herein are those of the authors and do not necessarily represent those of the Agency for International Development. Support was also provided by a Ford Foundation Grant to the University of Michigan Population Policy Committee. We received excellent cooperation from the National Family Planning Board and the Federation of Family Planning Associations in Malaysia. In the Philippines we received excellent cooperation from the staff of the University of the Philippines Population Institute, from the many family planning organizations, and from some members of the AID mission. Our debt to these persons is gratefully acknowledged. 
needed active programs of fertility control. Both countries had low levels of per capita output, both had strongly espoused goals of national economic development, and both had high rates of population growth that presented powerful obstacles to the achievement of the national goals. ${ }^{1}$ Finally, both countries were capable of doing something about population growth, since they both had rather extensive administrative structures that could bring communication and services to a substantial part of the population.

Despite the need, both countries were publicly opposed to mounting public fertility control programs. At the outset of his successful rural development program, the Malaysia Deputy Prime Minister, Tun Abdul Razak, vetoed the inclusion of family planning clinics in the district rural development efforts. He argued that the issue of family planning was a controversial one and should be left to the private sector. In the Philippines, the issue was scarcely raised, as no politician wished to risk confrontation with the Catholic church, which, whatever the realities, was believed to be a powerful political force. The objective need could be ignored, at least for the present, because of the specific formulation both countries gave to the demands and potentials for national economic growth. The high rates of population growth were seen not as conditions that had to be overcome; they were seen as conditions that made rapid economic growth imperative.

By 1970, the situation had changed drastically in both countries. Population growth had come to be defined as a crippling obstacle to economic growth, and both countries had moved to intervene publicly in the reproductive process to bring about a decline in fertility. But the change had a different pattern in the two countries, which reflected different political structures and produced critical differences in the process of decision-making and in the character of the fertility control programs that ensued. It is to these differences that we shall direct our attention. 


\section{MALAYSIA}

By 1965, Malaysia had completely reversed its policy. Population growth had been redefined and was seen as an obstacle to economic development. In that year, the government presented legislation for the creation of a National Family Planning Board. By 1967, the board had launched a national family planning program oriented primarily to providing the new oral contraceptive technology to Malaysian families. The existing national health facilities were used to bring the new technology primarily to Malaysian women. The program was developed in phases, with characteristic Malaysian administrative efficiency. It began in metropolitan government hospitals, moved progressively out to district hospitals, and then to rural areas. By 1970, the program had reached approximately 166,000 families with its 64 main clinics and its roughly 375 staff members (Federation of Malaysia, 1969).

Malaysia's change was led by the organizational instrument of national economic planning, the Economic Planning Unit. The forerunner of this agency was the Office for Economic Development and Trade, which the British colonial government located under the Secretary of Finance prior to Malaya's independence. When Malaya achieved home rule in 1955, this office became a part of the Prime Minister's Department, shifting its location from the center of financial power to the center of political power. This location change freed the economic planning office from the constraints of a purely fiscal mentality and forced it to be concerned with longer-range national goals. ${ }^{2}$

In addition to the location change, the office experienced a progressive development of organizational competence. The direction of the office was taken over by a professional economic planner, economists were added to the staff, and a series of research and accounting functions were added to give the office an increasing capacity to monitor the nation's economic performance. The office formally became the 
Economic Planning Unit in 1961, reflecting both the specialization and the competence it demonstrated in preparing the Second Malayan Five-Year Plan (1961-1965). ${ }^{3}$

Through 1960 and 1961, the EPU apparently shared the general view that the high rate of population growth was simply one of the conditions that made economic development imperative. By the end of 1962 and in 1963, this view began to change, largely as a result of the increasing work of economic monitoring that the unit was doing. In 1962, it received the results of an employment survey indicating that the progress that was being made in development was not sufficient to counter the structural character of the nation's unemployment, which was reflected in high rates of unemployment especially among the nation's youth. At the same time, the EPU learned from an ECAFE estimate that the 1957 census had underenumerated the number of nation's youth, which made the unemployment prospects even worse than they appeared. In 1963, the EPU undertook an interim review of the current five-year plan, which had the effect of sharpening the perception of the high economic costs of the nation's three percent-plus rate of population growth. The large-scale mobilization of national resources for public investment that the nation was achieving under the plan was not producing enough new jobs for the expanding labor force, but it was increasing the minimum level of public services, which produced a long-range commitment to rapid increases in public expenditures just to keep up with the levels of population growth.

This situation prompted the EPU to call on the Ford Foundation for technical assistance in assessing the long-term relation between population growth and economic development. The assessment was provided by Dr. Lyle Saunders, who argued that Malaysia did have a population policy, but that it was a policy that encouraged population growth. Furthermore, it was an implicit policy and therefore not subject to the kind of rational planning that was being 
undertaken for the economy as a whole. Finally, he argued that it would be possible to reduce fertility nationally, but that this would require a large-scale effort by the national government.

The EPU's changed perception of the population issue was transmitted to the cabinet through the National Development Planning Committee. This was a miniature cabinet, with strong EPU representation, that became especially active in the process of implementing the nation's rural development program. Rural development was primarily a program of public investment, in which the government consolidated its political power through providing a series of economically useful public amenities throughout the country, and especially in the rural areas. Through the NDPC the government leaders gained an expertise in long-range planning and coordination of public investment, plus a basis for a more rational ordering of the myriad lower-level political demands for public investment activities in specific constituencies. Thus, by providing government with a useful tool in political decision-making, the NDPC became a powerful mechanism for integrating work in economic planning into the centers of national political decision-making.

As the center of political decision-making, the cabinet also faced a series of political obstacles to a public populationcontrol program. One of these obstacles lay in the overt opposition of the Catholic population. Although the Catholic population has never been very large in Malaysia, between one and two percent of the total, it has been urbanized, mobilized, and articulate. Further, under colonial rule, the Catholic church and the Western churches in general, had occupied a rather favored and protected position. This gave the church far more political representation than warranted by numbers alone. The church was even represented at cabinet level by the respected Chinese leader, Tun Yew Koh Leong, who served as the nation's first Minister of Justice. Tun Leong represented the cabinet's public denial of requests 
for government assistance that came regularly from the growing private family planning associations that had been organized in all of the states. The Catholic opposition was eventually denied direct political articulation with the death of Tun Leong in late 1961. This may also be seen as the watershed that marked the demise of Western religious influence, and the emergence of Islam, the religion of the fifty percent Malay majority, as the dominant religious interest in government. That is, the Catholic religious objection was undercut when Islam came to power along with majority rule.

A second and more serious obstacle lay in the latent opposition of the Malay-Islamic interests. This opposition was undercut in two ways. In the first place, the government obtained a series of public statements of prestigious Islamic leaders in Egypt, Pakistan, Indonesia, and Malaysia to the effect that Islam was not opposed to fertility control and contraception. It was even argued that in its prescription for responsible parenthood and equality of treatment, Islam actually favored national population-control programs. In the second place, the Islamic opposition was denied a hearing on the basis of its racist appeal. Such appeals, known as communalist, posed an extremely dangerous threat to the stability of the multiracial nation and, as such, were explicitly proscribed. ${ }^{4}$ Thus in 1960 , the vice president of the Singapore Pan Malayan Islamic Party argued publicly that family planning should be avoided by the Malays, whose duty it was to produce more children for the party. Implicitly, this was an argument to produce more Malays, in order to keep the Malays from being overrun by Chinese and made a minority group in their own country. This relatively early argument served to define much of the Malay-Islamic opposition as communal and thus to deny it a hearing. The persistence of this type of opposition is still widely recognized in Malaysia, but it appears to have had little effect on the formulation of public policy or on the willingness of Malay women to seek and to utilize fertility control assistance. 
The government's capacity to deal with actual or latent political opposition was enhanced by the general character of the political structure in Malaysia (for a discussion in detail, see Ness, 1967: chs. 2-5). Almost from its inception, indigenous political organization has been highly centralized. In the Alliance form of government, a successful formula was developed for dealing with the explosive racial divisions in the country. This is a formula in which the basic units are ethnic parties-Malay, Chinese, and Indian-tied together in a central coalition party, the Alliance. The structure allows political leaders to mobilize masses on the basis of ethnic appeals, while at the same time these divisive and incompatible appeals are tempered and accommodated as the Alliance allocates resources and power in the relative isolation of its closed executive committee.

The Alliance emerged almost by accident in the first municipal election, in Kuala Lumpur, held in 1952. It was the first elected local government at the national level when it won 51 of the 52 elected seats in 1955, and it has continued in power through the elections of 1959, 1964, and even 1969 , though in the last election it was seriously weakened. Holding the reins of a parliamentary government, it has been in a position to exercise tight control over party members. This is facilitated by the lack of independent financial power among most party members and by the strong local organization the party has created in most states of the Federation. Thus, even highly popular elected leaders could be deprived of power by being expelled from the party if they failed to accept party leadership. ${ }^{5}$ Loyal members, on the other hand, could always be placed in safe constituencies to ensure their electoral victories.

Although the power of the party waned in the 1969 elections, the situation in 1965, when the fertility control legislation was enacted, was quite different. At that time, the Alliance party had just emerged from its overwhelming victory in the 1964 elections. Thus, the party had good 
reason to feel confident about its legislative initiatives where the fertility control program was concerned. ${ }^{6}$

Finally, the clearance of political obstacles was facilitated by the observed experience of private family planning activity. This began in 1953 with the formation of a state family planning association in Selangor. Associations were formed in a number of other states in the following years, all of which were represented in the Federation of Family Planning Associations formed in 1958. The associations received some government assistance intermittently from local authorities, and from the central Social Welfare Lotteries Board after 1961. They have also received external support from international family planning associations. But the bulk of resources has been mobilized locally both in the form of voluntary donations of time and money and from the sale of contraceptive techniques and services. The private organizations encountered Catholic opposition, but nonetheless proceeded to grow and to increase popular interest and acceptance in contraception. Thus they provided a wedge into the society for the acceptance of fertility control. In effect, government was encouraged to move ahead with a national family planning program by the observation that the private associations had been operating for over ten years without major political repercussions.

With strong economic arguments for fertility control effectively integrated into national decision-making centers, and with the political opposition undermined, the government proposed legislation for a National Family Planning Board in the legislative year 1965-1966. The legislation was approved by a well-controlled party-organized legislature, and the board began its operations.

From its inception, the Malaysian population control program has been primarily concerned with disseminating the new oral contraceptives to Malaysian women. Through 1969 , $92 \%$ of its more than 166,000 acceptors have used oral contraceptives. This use of the oral technology has had 
obvious advantages. It reduced personnel requirements by limiting the need for the highly trained medical doctors required in programs concentrating on intrauterine devices. The actual field operations could be managed by nurses, who were available in sufficient quantities to allow the program to expand rapidly through its initial three phases, where the target were women who were either fully urbanized or accessible from urban centers. In these three phases, there have been cnly four medical doctors available for the entire program, and two of these have been concentrated in specialized supervisory and training functions operating out of the national headquarters in the capital. Most of the 64 main clinics in operation at the end of 1969 were directed by a trained nurse or nursing sister. ${ }^{\text {? }}$

The recruitment advantages were enhanced by the specific social character of the labor pool from which the program was drawn. The board's program demanded work limited and stable in its schedule. Nurses in the government's medical services, on the other hand, were often required to work night shifts, and promotion depended to some extent on the willingness of the nurse to relocate to other towns. Thus, the board could easily draw out women whose family obligations were in conflict with their nursing career demands.

Throughout its first three years, the board's program has concentrated on the supply of technology and services to Malaysian women. Table 1 shows the allocation of total actual expenditures from 1966 through 1970 to the major organizational functions in the board.

It is evident that the major financial allocation has gone to the supply function. The same pattern can be seen in personnel allocations. By the end of 1969, the more than 215 field (supply) workers represented about $75 \%$ of the total 278 staff members in the entire operation. The distribution of the 215 field personnel at the end of 1969 is shown in Table 2. 
TABLE 1

Financial Allocations to Various Organizational Functions in the Malaysian Family Planning Board's Program 1966 through 1970

\begin{tabular}{lrrrrr}
\hline & 1966 & 1967 & 1968 & 1969 & $1970^{\mathrm{a}}$ \\
\hline Total budget (M \$000) & 249 & 900 & 1,600 & 2,000 & 2,216 \\
Administration percentage & 59 & 29 & 15 & 12 & 13 \\
Supply and service percentage & 0 & 43 & 63 & 70 & 65 \\
Training percentage & 0 & 3 & 2 & 3 & 5 \\
Research and evaluation & $41^{\mathrm{b}}$ & 19 & 8 & 6 & 4 \\
$\quad \begin{array}{l}\text { percentage } \\
\text { Information percentage }\end{array}$ & - & 6 & 11 & 10 & 11 \\
\hline
\end{tabular}

SOURCE: NFPB Annual Repart, 1969.

a. Estimates for 1970.

b. This was primarily for the initial Baseline Family Survey.

The data actually understate the function of information or value change, which is aimed at bringing about low-fertility norms among Malaysian women. A good part of the work of the supply personnel is motivation, as well as supply. The main clinics are located in proximity to the maternity wards of the district and metropolitan hospitals. The nurses who supply the services also make daily rounds in the maternity wards to visit women who have just given birth, and to induce these women to accept oral contraceptives. In addition, satellite clinics are sent periodically from the main clinics to the maternal and child health clinics that the

\section{TABLE 2}

NFPB Field Personnel by Functional Categories (Dec. 1969)

\begin{tabular}{lrr}
\hline 1. Primarily supply functions & 180 & $84 \%$ \\
Medical doctors & 2 & \\
Nurses & 102 & \\
Family Planning workers (board-trained & 76 & \\
$\quad$ nonprofessionals) & 11 & $5 \%$ \\
II. Information & 24 & $11 \%$ \\
III. Service: clerical, drivers, clinic servants & 215 & $100 \%$ \\
Total & & \\
\hline
\end{tabular}


medical service runs at least weekly in the smaller village and rural health subcenters. In these cases, the nurses combine pill provision with motivation, constantly attempting to gain more new acceptors to the program. Thus the activity of value change is more important than the data would indicate, ${ }^{8}$ but it is also important to note that it is closely integrated with the supply activity.

The operational goal of the program is defined in terms of a target number of women to be reached in the first five years. The target was not derived, however, from a calculation of the number of women who should be practicing family planning in order to bring about a reduction in fertility required for the achievement of long-term development goals (explicitly stated in the 1969 annual report). The target was arbitrarily set at a certain percentage (three percent, five percent, eight percent, ten percent, and ten percent for the respective five years 1967 through 1971) of married, child-bearing women. It represented essentially an assessment of what the board considered feasible for itself during its first five years.

A research and evaluation division reflects an attempt to develop the organizational competence necessary to monitor the program to provide a continued assessment of performance so that organizational adjustments can be made as needed to achieve goals. The division has developed quite a sophisticated reporting procedure, which can provide a sensitive account of both the quantity and quality of performance. A good part of the division's work has been concentrated in two major surveys: a baseline family life survey in 1966-1967, and an acceptors' follow-up survey in 1969 , with personnel subsequently allocated to a Census Post-Enumeration Survey on fertility control activity in 1970.

The annual report for 1969 notes that the target for 1969 was only $76.3 \%$ achieved. It explains that this was due to staffing and phasing problems. The board was moving into a 
fourth phase that would bring it into deep rural areas. Shortages of nurses presented an obstacle at this point. As a result, the board and the Ministry of Health have begun to work together on an integration of family planning services into the rural health services in an attempt to overcome problems of staff shortage. It is evident that the board has not yet developed the overall organizational capacity to utilize its available information to control its own performance. It does not set targets for individual clinics, nor does it use the information on the performance of clinics to control their operations (the 1969 annual report rejects the use of such individual or clinic targets and incentive plans). The move to integrate family planning with health services reflects a pattern of organizational control in which primary attention is still given to environmental factors rather than to internal control of performance. Internal control is provided for by initial and periodic refresher training courses, and by reliance upon established procedures, with rewards fixed by established positions rather than by performance.

In its general character, the family planning program bears strong resemblance to other development programs in which Malaysia has engaged, and which have shown considerable success, albeit in their fairly limited arenas. Like the rural development program, and its most successful subunit, the land development program, the family planning program is oriented to an increase in the provision of goods and services that the administrative structure is already capable of providing. The provision of goods and services takes precedent over attempts to change values and attitudes or direct attempts to change the social and economic structure of the nation. We have argued previously (see Ness, 1967: ch. 5) that this orientation fits the delicate ethnic composition of the country quite well, providing maximum rewards for the population and the government and minimizing the severe racial strains that would arise from more direct and urgent attempts to change the social and economic structure. 


\section{THE PHILIPPINES}

In 1967, President Marcos of the Philippines signed the United Nations' Declaration on Population. Subsequently, the Philippines legislature issued a joint declaration recognizing the seriousness of the population issue. These were merely statements, however, with no manifestation in concrete action at home. ${ }^{9}$ At the beginning of 1969, President Marcos did take the action of creating a Population Commission to study the issue and to advise on a national policy. Finally, just after the election of 1969, and in his subsequent state of the nation address, the President announced that the country would have a population program that would attempt to reduce the nation's high level of fertility. It is still problematic, however, just what concrete action will follow from this new orientation.

This move to a population-control policy was not initiated in Philippine centers of development planning. This was not, however, due to the absence of such centers nor to their lack of sophistication in planning matters. The Philippines has had development organizations at least since the National Economic Council (NEC) was created in 1935. Its reactivation after the wartime destruction offered at least the possibility that organizational competence in development planning would grow. In its formal structure the NEC was designed to develop competence in monitoring the nation's economic development, in transmitting knowledge and advice to the President, and in integrating its knowledge and advice into both the legislative and executive branches of government.

There has been considerable growth in both the sophistication and technical competence of the NEC (see, e.g., Milne, 1960, for an extensive review of NEC, its problems, and prospects until 1960). It was reorganized in 1955, giving it a full-time chairman and an enlarged economic staff. Subsequently, the NEC made considerable progress in organizing national data collection and analysis for economic develop- 
ment. It has worked in cooperation with the Central Bank to develop and perfect the national income accounts, designed the national Annual Survey of Manufactures, and initiated the Statistical Survey of Households (Milne, 1960: 176). All these provide valuable information necessary for the process of development planning. Finally, the NEC has created a number of development plans, each showing an increase in sophistication and comprehensiveness. There has been, thus, an impressive development of the technical capacity to participate in the development planning.

This developing technical capacity has provided a growing body of data on population and economic growth. A 1958 survey found unemployment ranging from seven to ten percent of the labor force, with over twenty percent of the employed wishing additional work (National Economic Council, 1958: 2). These were considered serious levels of unemployment and underemployment. Two articles in the NEC's Statistical Reporter in 1958 and 1959 called attention to the very high rates of population growth in the country, the prospects of continued high growth rates, and the economic problems this implied (Aromin, 1959, 1958). Food balance sheets, nutritional surveys, analyses of income distribution, the condition of housing, levels of literacy, and the implications of population growth for educational costs came in a steady stream from the NEC Office of Statistical Coordination and Standards. All these studies pointed to the high costs of population growth, but this knowledge appears to have had little if any impact on policy formation.

Although the NEC developed the technical capacity to monitor economic conditions, it has never been fully integrated into the national centers of decision-making. The reorganization of 1955 was prompted by the recognition of the impotence of the NEC in matters of effective development stimulation. But the reorganization had little effect. After five years of a new structure with a full-time chairman, the 1960 review concluded that the NEC had been a failure 
as a development agency (Milne, 1960: 1-5, 184-204). Its three development plans to that date had not been approved by the President. The position of the chairman had been left unfilled for two years. The organization competed, badly, for presidential support with a myriad of other agencies. The Budget Commission and the Fiscal Policy Council were both superordinate in planning matters; both had the direct ear of the President; the NEC had not.

A number of reasons for this failure were put forward in the 1960 review. It was pointed out that the techniques for planning were well developed; what was lacking was the capacity to implement (Milne, 1960: 37). Another observer noted that "the whole set-up reveals overlapping of authorities, contradictory decisions, and absence of coordination and integration" (see Milne, 1960: 79). The editor, R. S. Milne, offered a more general diagnosis. There was a constant lack of strong executive support for the NEC or for any concerted planning effort. In general, the NEC, and its development planning had failed because:

there has been too great emphasis on the virtues of checks and balances and too little on making the machinery sufficiently po'verful and streamlined to carry out successful planning. What is needed is more horse power in the engine and less preoccupation with the refinements of the braking system [Milne, 1960: 203].

Since 1960, the picture has not altered greatly. The NEC has remained impotent for all practical purposes in the area of integrating development thinking into government decision-making. This has led to a pattern of administrative organization peculiar to the Philippines. Each of the two successive presidents has been concerned with the problem of implementing development policies, and each has attempted to establish distinctive organizational units for implementation.

President Macapagal created the Program Implementation Agency (PIA) in 1961 to attempt to get some action into 
government development policy. This created considerable hope for a time and brought a series of young and dynamic men into government. Clair Wilcox (1965), writing of this period, likened it to the early days of the New Deal in the United States. Sixto Roxas, a dynamic young businessman, was brought in to head PIA. The coordination that this effort required, however, proved too much for the Plilippines political system. The President was unable and unwilling to give Roxas the support he needed to coordinate programs effectively. Within a year, PIA had threatened too many legislative and administrative interests and Roxas was moved to head the NEC. Not long afterward, he left government to return to business. ${ }^{10}$

President Marcos used his office of Executive Secretary, headed by another dynamic young leader, Rafael Salas. Marcos transformed PIA into the Presidential Economic Staff designed to do the job of development planning. Salas, too, recruited a group of active young technocrats and set about promoting certain aspects of development. It was his office, not the NEC, that drafted the four-year plan for Marcos' first term, 1967-1970. It was Salas' office that was largely responsible for the considerable progress the Philippines made in rice production during the last years of the 1960 s. His office also provided a means by which the technically competent persons and organizations interested in population planning began to gain access to the President. But the long-term implementing capacity apparently failed again, reflected in Salas' resignation before the 1969 elections.

Even if the NEC had been closely integrated with presidential levels of decision-making, it would not have been an open channel for the promotion of population control interests over the past few years. The chairman of the Council, Placido Mapa, has been an outspoken foe of population control programs. Representing strong and orthodox Catholic views on fertility control, Mapa has also argued 
that the population problem could be solved through economic growth and industrialization, and that family planning would in fact impede the Republic's industrialization program (Manila Chronicle, 1960).

NEC's opposition to family planning did, however, present an obstacle to a major source of initiative in population control matters. From 1967, U.S. AID has had a strong interest in promoting fertility control programs in the Philippines. Technically, all external aid must be channeled through NEC, and the chairman obstructed efforts to provide external support to fertility control programs in private and local government organizations. Thus, in 1968, U.S. AID entered into an agreement through the NEC with the Department of Health to create a Project on Maternal and Child Health (POMCH). One of the functions of the POMCH was to coordinate all U.S. AID assistance to health programs that included family planning. This has allowed AID to mask some of its family planning assistance, to bypass the bottleneck of NEC, and to deal directly with supporters of family planning programs among a variety of Philippine elites.

There has been no lack of such supporters. Throughout the Philippines there are a large and growing number of persons and organizations concerned with the promotion of family planning programs. It is one of the paradoxes of the Philippines political structure that, although it is highly centralized in its formal structure, it is in fact highly decentralized in actual operation. Thus there has been at least a decade of growing activity among private organizations and local government agencies in promotion of fertility control (Perkin, n.d.). A number of Protestant centers-such as Silliman University in Dumaguete City-Negros, Oriental, and the Capiz Baptist hospital on Panay-have pioneered in family planning programs, showing considerable activity since the mid 1960s.

In addition, municipal and provincial governments have been able to engage in fertility control programs if the 
specific leaders were so inclined. Thus, the Manila Health Department (MHD) established family planning clinics, using the rhythm method, as early as 1960. With training for professional staff provided by the Singapore government in 1965, the MHD opened five pilot clinics providing assistance using all contraceptive methods. The pilot project grew to a program with more than twenty clinics, which could receive direct support from AID. It appears that the mayor was at least offically unaware of this progress, which was led by powerful medical officers in the MHD. Similarly, the Davao City Council began a family planning program in 1967 , combining formal approval of the mayor and the city council with direct financial assistance from AID.

The support from AID has been crucial in obtaining family planning program action in the Philippines. Either directly or through its support to the International Planned Parenthood Foundation, U.S. AID has provided the major portion of financial support for family planning programs in the Philippines. AID only began providing financial assistance to Philippine family planning programs in FY 1966-1967, with a grant of $\$ 20,000$ (see Manila, City of, 1970). Since that time, the figures have climbed rapidly with allocations both from AID Manila and AID Washington through IPPF and the Pathfinder Fund. The obligation from AID Manila for 1969-1970 was $\$ 1.4$ million, bringing the entire AID contribution to that time to almost $\$ 3.9$ million. This amounted to about eighty percent of the total of $\$ 4.9$ million available from major external sources (Sycip et al., 1969).

This sudden and large-scale infusion of financial support for family planning has been one of the central facts of life for the Philippines programs. It provided large-scale support for the large number of highly qualified doctors, demographers, and programmers in the Philippines who have been concerned with population growth for some time. It also served to reward whatever interest there was in population control, thus drawing out a good deal of latent interest 
throughout the country. For example, the Davao City program was prompted in part by the suggestion that external financial assistance would be available for a family planning program.

In addition to stimulating organized interest in family planning in the Philippines, the AID assistance has resulted in a large-scale proliferation of organizations, each claiming rights of access-sometimes original rights of access, and often rights of exclusive access-to the financial resources that are being made available. That is, AID's assistance has created an arena marked by a high degree of interorganizational competition.

A major source of opposition to or inertia concerning public fertility control programming in the Philippines has been the Catholic church, the putative spiritual leader of the great majority of Filipinos. While this is scarcely an unexpected observation, the specific role of the church, or of religion in general, on this issue, is by no means simple or direct. Individual priests have made statements against family planning charging immorality of unnatural methods, but the church has made no specific public statement against family planning. Even issuance of Humane Vitae brought no open statement from the church. Nor would the church allow itself to be drawn into a public debate on the issue. A group of liberal priests and lay persons presented an open letter to the Catholic hierarchy on September 27, 1969, challenging the church to come out in the open on the issue of family planning (Manila Chronicle, 1969). The church remained silent.

Part of the reason for the church's silence lies in its own crisis of authority. It is quite clear that the hierarchy is no longer a monolithic structure with a secure authority. Its traditional stand on birth control is being contested openly by priests and even bishops in the Philippines. Church officials can be found representing every position known in the lay public on birth control. Some priests and bishops 
openly advocate birth control, some even allowing any means; others make sharp distinctions between methods that destroy life and those that do not; and, of course, still others hold to the orthodox position. The issue goes far beyond birth control, of course, and represents the wider issue of the extent of authority that actually resides in church offices. It is quite likely that the church would have a great deal more to say about family planning if it were more certain of its ability to exercise its authority, especially over its own priests and bishops.

Whatever the reason, the church's silence on population planning did not reflect accurately the public mood. Newspaper discussion of population pressures has been growing rapidly over the past half-decade, rising from a scant dozen articles at mid-decade to about 150 articles in 1969 for the Manila English dailies. The single most important vernacular press, TALIBA, saw a similar increase from about a dozen articles in 1965 to 35 in 1969. The presidential creation of the Population Commission in February of 1969 received wide coverage and support in the press. In addition to the more common concern with population pressure and economic development, the Philippine leaders pointed to some very specific evils of such pressures at home. Dr. O.D. Corpuz, then Secretary of Education and Chairman of the President's Population Commission, argued publicly in September 1969 that the current crisis in the schools, which saw radical movements and violent student unrest, could be blamed on the population explosion.

This would indicate that the family planning issue lay close to the surface in the 1969 election. Regardless of how close, however, it was definitely below the surface. As the election approached, the Population Commission delayed and postponed its meetings, and it held off presenting its recommendations to the President until after the elections. There was an obvious reluctance to open this Pandora's box in the Philippines political arena. But, in addition, the issue itself 
appeared far from the fronts of the minds of the political leaders. A survey of eighty winners and losers in the election (including 29 senatorial candidates, 36 congressional candidates, 8 governors elected in 1967, and 5 cabinet members) showed a great lack of interest in the population question. Less than half said they had stated their views on family planning, but even among these, more than a quarter had only stated their views among close friends. Virtually none (three of eighty) saw the family planning issue as a political issue in the 1969 elections. Only one voluntarily indicated the population problem as a national issue of first importance; after probing, only nine more recognized the problem as important for the nation. This seems to be more attributable to a simple lack of knowledge than to the perception of the adverse effects of open discussions on the population issue. Only one-quarter of our respondents were able to name at least one family planning organization in the Philippines. And fully sixty percent of the respondents thought that taking a stand for family planning would have no effect or no adverse effect on popular support. Almost as many thought it would increase popular support as thought it would decrease popular support ( 17 versus $23 \%$ ).

The picture of the polity presented by informants fits the above data fairly well. Most politicians were not interested in population problems. They either did not consider them important problems in any sense, or they did not consider them important enought to risk a confrontation with the church. It might be generally known how the church stood on family planning, but no one knew how much popular support the church had on this issue. More important, no politician was eager to test the power or influence of the church over the electorate in the head-on clash. As usual, most Philippine politicians preferred to hedge all bets, to be all good things to all people.

In the Philippines, then, the political dynamics of the decision for a population control policy include: 
(a) significant external support and initiative through AID, which is provided to

(b) active private and local public bodies supporting population control policies, with

(c) a generally favorable climate of public opinion, and

(d) relative silence from the major institutional source of opposition, the Catholic church.

In contrast to Malaysia, neither the nation's political leaders nor its specific development agencies have been significant initiators in the decision for a population control policy.

We have already observed the considerable organizational competition that has resulted from the large influx of AID funds. It is as yet too early to say what will be the outcome of this competition or of the presidential policy decision, though given the past experience of the Philippines polity on development issues, we can safely predict that the outcome will not be a simple one. One group that at this point deserves special attention, however, is the Responsible Parenthood Council (RPC). This is a council led by a group of young technocrats, who were originally associated with Secretary Salas' office. They have proposed that the high dispersion of the Philippines population in thousands of small barriors requires a special type of approach in order to provide the impact on national fertility that is required by the excessive rate of population growth. They have proposed a program similar to the country's Community Development Program, in which the church and the local barrio government would be involved in leading the way to new family and fertility values in the nation. The program rests heavily on the need to change values and attitudes of the rural population, hence the importance of gaining support from the church hierarchy and local government officers.

The issue of the technology to be used is less clear, though perhaps deliberately so. The program leaders have drawn together a select series of studies indicating that the rhythm 
method can be expected to have a good effect. This, naturally, appeals to the Catholic hierarchy. So much so, in fact, that the Bishops Conference officially endorsed this program as its own program in January 1970. The Conference President, Archbishop Gonzaga, even observed, in this closed meeting, that this endorsement would be the hierarchy's reply to the challenge from the liberals to take a stand on family planning.

Perhaps the most significant aspects of this program lie in two things: one is its good chance of success in the interorganizational competition for external resources and presidential favor. The other is the similarity in the style of development activity with the community development program, and with a number of other Philippine development programs. To take the second aspect first, we note that the emphasis is on value change. Major activities will include meetings, seminars, and training programs. Village-level workers will be produced to go into the barriors to organize Rural Family Units in each of the country's 25,000-plus barrios. Local leaders, priests, school teachers, elders, active young married couples, and so on will be organized to hold meetings to talk about family planning, to present the rationale behind responsible parenthood. This pattern of creating local groups for self-help, for mobilizing the local population, for discussions, and for value change has been a dominant part of Philippine rural development programs almost since independence.

The impression that the RPC has a good chance to succeed derives from two observations. First, it was the first proposal to be approved by the NEC-POMCH review for an AID grant in May 1970. Second, its close support from the church, the medical profession, and the armed forces, as well as AID, provide it with the broadest base of support of any existing organization.

At this point, one real danger emerges for the program. It is possible that the success of the program in the interorgani- 
zational competition will be achieved at the price of program success in fertility control. The successful acquisition of broad-based support could mean that the program would remain focused on value change rather than upon technological diffusion. The scenario for this type of program would be one in which progress is measured in terms of the number of village-level workers trained, the number of village-level units organized, the number of meetings held, and the number of couples contacted. There would be relatively little attention paid to the supply of contraceptive techniques and to the integration of supply with motivational activity. Thus. the program would emerge as a talking campaign with little or no appreciable impact on fertility. There is the allied danger that the program will be utilized as a political tool by the President's office. That is, it will be used by the President to mobilize voter support for himself. ${ }^{11}$

\section{DISCUSSION}

This analysis brings out three sets of variables that are significant in such public policy matters as represented by population control programs. One set concerns the political system and its planning mechanisms and will be treated as a set of independent variables. The other two sets of variables will be treated as dependent variables. They include one set concerning the decision itself: the speed with which the decision was made, the sources of the decision, and the executive action that results from the decision. The final set of variables concerns the character of the programs that ensue from the public decision to have a population program.

The Philippines and Malaysia represent two different types of political systems. In the furst place, the Malaysian system is centralized, while the Philippines system is decentralized. This refers, of course, not to the formal structure, which shows just the opposite character, but to the operative system. In Malaysia, the party is a powerful political organization. Individual members are subject to party dis- 
cipline, since the party effectively determines who will be elected, and what will be the allocation of a wide range of powerful rewards, including personal perquisites, as well as amenities for one's constituents. The Philippines party system is notoriously weak. Congressmen and senators usually have (or gain when in office) considerable personal wealth, they have their own personal political organizations, and they usually get themselves elected.

Second, the specific importance of the development process has been quite different in the two political systems. For the Philippines, economic development per se has evidently been of little political importance. There has been little effective presidential support for development planning and implementation. In Malaysia, the opposite is nearer the truth. The specific and precarious formula for ethnic political accommodation worked out in the successful electoral arena from 1952 through 1955 made it imperative that large-scale modern amenities (or social overhead capital) be provided for the rural Malays without threatening the vested economic interests of the urban Chinese and Indians. Thus, development efforts, first for more schools in 1955 and finally for roads, land, and other capital features after 1959 became important activities for the consolidation of political power.

Third, given this set of sequences, it is understandable that the integration of development planning and political decision-making would be quite different in the two cases. In the Philippines, the very provisions that were designed to integrate development planning into the center of the nation's decision-making processes had just the opposite effect. Regular legislative members on the NEC made it impossible for the President to take that body seriously, even when it did develop the technical capacity to provide useful intelligence on development processes. Development plans prepared by the NEC were unapproved by the President, or, even when they were approved, they had little direct impact on the nation's actual economic policy. In Malaysia, on the 
other hand, the planning unit was closely tied to the cabinet through the National Development Planning Committee, which received the political power it needed through the active involvement of the Deputy Prime Minister. Plans made were not only accepted by the cabinet, they were translated into five-year allocation schedules integrated with the federal budget. The allocations were further translated into specific projects with target dates set by the agencies responsible for their implementation.

In the Philippines, the NEC developed the capacity to assess the negative impact of population growth on economic planning goals as early as 1958 , but this never became an important input in the nation's decision to have a population control program. In Malaysia, the EPU gradually came to see the magnitude of the costs of population growth in 1962 and by 1965 had translated this intelligence into a decision for a population control program.

The impact of these political system differences on the decision for a population control policy has been crucial. The decision for a population control program came in Malaysia relatively speedily; it came largely from internal sources directly concerned with the process of national economic development, and when the decision was actually made, it was followed by effective executive action. Although the EPU has roots that go back to 1952 and was strategically relocated in 1955-1956, it was not until its enlargement and reorganization in 1960-1961 that it could be said to have gained the competence needed to assess accurately the impact of population growth on economic growth. This assessment really occurred in 1962-1963, especially with the interim evaluation of the current five-year plan, and was followed in two to three years with a new population control program. The major source of the impetus for this change came from within the development organization itself, thus also from within the nation itself. And when the decision was made, the government acted with a decisiveness that reflected 
both a considerable concern for the problem, and its own sense of power to initiate what it thought best for the nation.

In the Philippines, the decision for a population control program has been slow in coming; it has arrived only with considerable external pressure; and even as it is being made, it is equivocal and lacking forceful executive action. From the reorganization of the NEC in 1955, another fifteen years were required for the political leadership to announce a program of population control. That decision was helped along considerably by the very large amounts of external funds and external influence provided by the U.S. AID. This is not to deny recognition to the substantial fertility control interest groups within the Philippines, largely concentrated among the development-oriented intellectuals. Without such forces, whatever external assistance would have been available would have come almost in vain. But it also seems incontrovertible that the sudden opening of the financial floodgates of AID, and the strong interest AID officials had in promoting a national population control program in the Philippines, was a very substantial factor in inducing the national leadership to make a decision for a program. When the decision was made, however, it came as a somewhat hollow decision. Legislation would be forthcoming; the President had just entered this new arena of interorganizational competition and would certainly concentrate his efforts in that arena on making the competition work to his advantage. Whereas, in Malaysia, the decision for a program was the signal for initiating decisive executive action, in the Philippines the same decision was the signal for executive manipulation of other centers of initiative to the end of enhancing executive political power.

This series of relationships, between political system characteristics on the one hand and the speed, pattern, and decisiveness of the move to a population program on the other, appears at least logical and plausible. The final relationship must be advanced more tenuously. Each political 
system tends to give rise to public programs that show a general style or orientation distinctive to that system. Like its other development programs, the Malaysian population program is oriented to the provision of goods and services; like its other development programs, the Philippines program will probably be primarily concerned with changing values and attitudes.

We have previously argued that supply and service-type programs fit the political culture of Malaysia quite well, and that value-oriented programs were dysfunctional in that they amplified the strains inherent in Malaysia's plural society (Ness, 1967: ch. 5: see also Ness, 1964: 397-417). The major cleavage in Malaysian society-between Malays and Chinesealso represents a cleavage between different, even antithetical, value systems. The work and achievement orientation of the Chinese value system contrasts with the consumption and ascription orientation of the Malay value system (see esp. the revealing argument in Mohamed. 1970). It seems generally believed that the value system of the Chinese is functional for modernization, while that of the Malays is dysfunctional. Thus, programs that focus on value change tend to appear as prescriptions for Malay values to change in the direction of Chinese values. In focusing on such issues, value-oriented programs lay bare and amplify the normative divisions within the society, thus obstructing efforts at collective resource mobilization. There is considerable history of experimentation with this orientation in Malaysia, but in almost all cases it has been rejected, precisely because of the strains it induces in the polity. Supply and service programs, on the other hand, have been found to be capable of distributing social rewards quite generally without encroaching too heavily upon the interests or sensitivities of any group. Further, supply and service programs have been found to be highly functional for consolidating political power and for facilitating collective resource mobilization. It is important to our thesis that the decision for a population program came just 
after the most successful experience in using supply-type programs for the consolidation of power. That is, the decision in 1965 followed immediately upon the overwhelming success of the government party in the 1964 elections. Although there were a number of reasons for that electoral victory, one of the major reasons was the successful implementation of a supply-oriented rural development program that increasingly gained momentum over the preceding five years. Thus, it is at least understandable that this successful formula would be applied again in the case of the population program. ${ }^{12}$

The tendency for development programs in the Philippines to take on a value-change orientation seems similarly related to the operation of that political system. The consolidation of political power derives from a series of shifting coalitions among particularistic groupings and economic interest groups. Regional-language groupings, bodies of personal followers, and economic interest groups such as sugar and real estate are brought together especially around elections and loosely held together through a series of legal and illegal patronage acts. ${ }^{13}$ The bureaucracy itself represents more a collection of sinecures than a series of instruments for collective action. Thus, each successive president creates new agencies in order to obtain new posts and to give an image of distinctiveness to his administration. Rationally organized formal structures for control are created, but little work of control is actually put into them. The system works well to reward the series of semi-independent power holders, but it has never seemed very effective in achieving collective development goals. It is definitely not the type of system in which development programs have been used to consolidate political power. Thus, presidential support has always been lacking for development programs.

In this system, value-oriented development programs produce the maximum of gains and minimum of strain. They allow for considerable publicity and fanfare, considerable 
visible activity, and a considerable number of positions that can be used as patronage. They do not require the forceful application of power that is necessary if actions of various agencies are to be coordinated and forced to increase supply and services to the population. And they protect the administration from the embarrassment of failure, since performance is evaluated not in terms of physical output or of increased income, but in terms of meetings, discussions, contacts, ard talks. Success defined in terms of the process, rather than in terms of its outcome, is always easily demonstrated.

Thus, at least a plausible explanation can be made for a series of observed relationships. In Malaysia, the highly centralized political system in which development efforts were important in the consolidation of political power saw a relatively rapid and decisive move to population control programs, in which the initiative for the movement came largely from within the nation from its own centers of development planning. The resultant program was supplyoriented and produced the immediate impact of making a new contraceptive technology available to increasing numbers of families. This should be expected to produce an immediate impact in the direction of fertility decline. though the long-term impact remains more problematic. On the other hand, in the Philippines, a highly decentralized political system in which development efforts were not important in the consolidation of political power saw a slow, equivocal move to a population program, in which the initiative came to a large extent from outside the society. The resultant program is likely to be heavily oriented to value change and cannot be expected, by itself, to have much of an immediate impact on the level of fertility in the nation. 


\section{NOTES}

1. The Population Reference Bureau presents the following figures for 1969 :

$\begin{array}{lrc} & \text { Malaysia } & \text { Philippines } \\ \text { GNP/Capita } & \text { US } \$ 280 & \text { US } \$ 160 \\ \text { Population growth rates } & 3.1 \% & 3.5 \%\end{array}$

2. The importance of this location change was evident during the 1957 recession. In his new political location, the previously fiscally conservative British officer argued against retrenchment of government expenditures; on the other hand, the new indigenous Minister of Finance, previously highly vociferous in defense of a more expansive fiscal policy, argued strongly for retrenchment.

3. Although this is named the Second Five-Year Plan for Malaysia, it was in fact the third formal planning exercise. The first had been a draft plan prepared in 1952. On the other hand, this second plan was really the first attempt at national economic planning worthy of the name, and even this was quite modest in its scope. Subsequent plans have been the First Malaysia Plan, 1966-1970 and the current Second Malaysia Plan, 1971-1975.

4. Even before the racial violence of the 1969 elections prompted the government to outlaw appeals to ethnic sentiments in public political meetings, there were such rules for specific situations. For example, Parliament has had a rule against uttering statements that might have the effect of rousing communal sentiments.

5. The most celebrated case in point is that of Aziz bin Ishak, Minister of Agriculture from independence until 1962. Though a very popular leader, he failed in his bid for independent election after he had been expelled from the party for pressing against Chinese rice milling interests in Perak and Province Wellesley.

6. Government confidence in legislative assent is indicated by the public announcement of the establishment of the National Family Planning Board before the legislative debates and approval had taken place.

7. A few of the small, one-nurse clinics have been run by assistant nurses, or by Family Planning Workers, lay women wholly trained by the board.

8. In a study of clinic operations, we found that $41 \%$ of the total number of interactions between staff and patients were for motivation, the remainder being primarily for new acceptors and revisits of women for a resupply of Pills. If we can use this $41 \%$ as a norm of the educational work done in the supply functional category, we obtain an overall equality between supply and education. with each claiming about $40 \%$ of the total resource allocation. It should still be noted, however, that about $70 \%$ of the education work is done within the supply function. That is, there is close structural integration of the major portion of the value change work with the dominant supply function.

9. One can even read significance into the space allotted to population problems in the joint declaration. Only roughly $3 \%$ of the total space of the 
declaration is devoted to population, and this to a statement that spoke first of meeting the growth pressures through programs to increase human productivity and only subsequently through programs to decrease human reproductivity. See Sixth Congress of the Philippines (1969).

10. Successful implementation of development programs requires the coordination of specialized agencies. This in turn requires the active application of power above the agencies to establish priorities, settle jurisdictional disputes, and to create new interagency patterns of communication. In Malaysia's successful rural development program, we saw the critical importance of the active use of power by the Deputy Prime Minister (see Ness, 1957). The failure of PIA and Roxas' subsequent disillusionment with government development programs in the Philippines can be traced directly to the inability or unwillingness of the President to supply the power needed to coordinate existing agencies.

11. There are present rumors that the first lady, Mrs. Marcos, is giving her support to the family planning program in an attempt to take over its leadership. This would give her access to resources for mobilizing workers for her own political support. This is the more significant in view of the persistent rumors that Mrs. Marcos plans to run for the presidency in the next election, since her husband is prohibited by the constitution from running for a third term.

12. The rural development program lost considerable momentum after the election of 1964, which accounts in part for both the electoral reverses and the racial violence of the 1969 elections. It is quite likely that if the population program decision had been made following 1969. rather than 1964, it would have been quite a different decision. At the very least, we could expect that the decision would have been considerably delayed.

13. On the importance of regional-language groups, see Ando (1969); on personal and economic interest groups in Philippines politics, see Hollensteiner (1963), Lande (n.d.) and Abeuva and de Guzman (1969).

\section{REFERENCES}

ABEUVA, J. V. and R. P. DE GUZMAN [eds.] (1969) Foundations and Dynamics of Filipino Government and Politics. Manila.

ANDO, H. (1969) "A study of voting patterns in the Philippine residential and senatorial elections, 1945-65." Midwest J. of Political Sci. (November): 567-586.

AROMIN, B. B. (1959) "Demographic aspects of Philippines economic growth." Statistical Reporter 3 (October).

-- (1958) "The demographic situation in the Philippines." Statistical Reporter 2 (June): 1-6.

Federation of Malaysia (1969) Annual Report of the Family Planning Board.

HOLLENSTEINER, M. (1963) The Dynamics of Power in a Philippine Municipality. Manila.

LANDE, C. (n.d.) Leaders, Factions, and Parties, the Structure of Philippine politics. 
Manila Chronicle (1969) September 27.

-- (1960) September 13.

Manila, City of (1970) "Progress report on the Family Planning Program, 1965-69." Department of Health. (mimeo)

MILNE, R. S. [ed.] (1960) Planning for Progress. Manila.

MOHAMED, M. (1970) The Malay Dilemma. Singapore.

National Economic Council (1958) Statistical Survey of Households, Series 3, June.

NESS, G. D. (1967) Bureaucracy and Rural Development in Malaysia. Berkeley: Univ. of California Press.

--- (1964) "Community development and public investment: the programming and economic development in Malaysia." Developing Economies (December): $397-417$.

PERKIN, G. (n.d.) "Family planning in the Philippines." (mimeo)

Population Council (1968) "Population and family planning programs: a factbook." Reports on Population/Family Planning (December).

Sixth Conference of the Philippines (1969) "Joint resolution establishing basic policies to achieve economic development and attain social justice." Philippine J. of Public Administration (October): 479-484.

Sycip, Gorres, Valayo and Company, C.P.A. (1969) "U.S. AID, Manila, Family

Planning in the Philippines." Management Services Division.

WILCOX, C. (1965) "The planning and execution of economic development in Southeast Asia." Occasional Paper in International Affairs 10, Harvard University Center for International Affairs.

\section{Regional Problems and}

\section{Policies in}

\section{Italy and France}

by KEVIN ALLEN and M. C. MacLENNAN

Regional Problems and Policies in Italy and France provides comprehensive background analysis for those who wish to understand how regional policy works in three important European countries-Italy, France, and the United Kingdom. It is essential reading for the student of Western European governmental policy and/or the European Economic Community, with its authoritative and detailed study of the implications for regional policy of British Common Market entry.

ISBN 0-8039-0093-7

L.C. $78-137829$

1971

SAGE PUBLICATIONS, INC.

75 S. Beverly Dr. / Beverly Hills, CA. 90212
368 pages

$\$ 13.50$

Market: USA and dependencies 